45 Chamberlain SR, Sahakian BJ. The neuropsychiatry of impulsivity. Curr Opin Psychiatry 2007; 20: 255-61.

$46 \mathrm{McGaugh} \mathrm{JL}$. The amygdala modulates the consolidation of memories of emotionally arousing experiences. Annu Rev Neurosci 2004; 27 $1-28$.

47 Christenson GA, Mackenzie TB, Mitchell JE. Characteristics of 60 adult chronic hair pullers. Am J Psychiatry 1991; 148: 365-70.
48 Christenson GA, Ristvedt SL, Mackenzie TB. Identification of trichotillomania cue profiles. Behav Res Ther 1993; 31: 315-20.

49 du Toit PL, van Kradenburg J, Niehaus DJ, Stein DJ. Characteristics and phenomenology of hair-pulling: an exploration of subtypes. Compr Psychiatry 2001; 42: 247-56.

50 Boughn S, Holdom JJ. The relationship of violence and trichotillomania. J Nurs Scholarsh 2003; 35: 165-70.

\title{
The Most Serious Moment of Our Lives
}

\section{Poems \\ by doctors}

\section{Ron Charach}

Years later as Mindy began to unravel,

and rolled on the hospital floor

when she failed to get her way,

her second drink of lye

impressing not one soul

in her exhausted family,

they all agreed to

plug her into the wall

when the fourth and final round of pills

failed to work.

Wheel her back when you're finished,

head turned over on its side

so she can't breathe her vomit,

meaning no aspiration.

But when her eyes unsealed in the white tiled room,

and she hoarsely called for water,

she recognized my role in this,

my professional ring through the plastic.

She may have seen a liar straining

to escape from my face,

because instead of asking about her husband

and the kids,

and who knew,

and did everybody know,

instead, she turned her electric breath on me.

Automatically, I told her, "Shhh, It's okay now ... ."

but she looked me up and down and said, "This

is the most serious moment

of our lives."

Ron Charach was born in Winnipeg, Canada. He studied medicine in Toronto and trained in psychiatry in New York. He has lived in Toronto since 1980. The two poems are from Selected Portraits. Hamilton, Wolsak \& Wynn Publishers.

Poem selected by Femi Oyebode. 